\title{
INVESTIGATION OF ASPHALT PAVEMENT WITH ADDED CRUMB RUBBER
}

\author{
Ján Mandula \\ Faculty of Civil Engineering, Technical University of Kosice, Department of Geotechnics and Traffic \\ Engineering, Slovakia, Doc. Ing.

\section{Tomáš Olexa} \\ Faculty of Civil Engineering, Technical University of Kosice, Department of Geotechnics and Traffic \\ Engineering, Slovakia, PhD. student

\section{Mariya Holubka} \\ Faculty of Civil Engineering, Technical University of Kosice, Department of Geotechnics and Traffic \\ Engineering, Slovakia, Ing. PhD.

\section{Brigita Salaiová} \\ Faculty of Civil Engineering, Technical University of Kosice, Department of Geotechnics and Traffic \\ Engineering, Slovakia, Ing. PhD.
}

\begin{abstract}
Waste tires must be recycled in environmentally safe ways that meet civil engineering concerns while fulfilling standards for construction materials. Used tires can be processed into rubber powders with particle sizes of $0-2 \mathrm{~mm}$, a suitable fine aggregate for mixing into road pavements. We tested asphalt mixtures with rubber added using the dry method, comparing their properties with a traditional mixture. We tested asphalt-rubber mixtures with rubber incorporated at either ambient temperature or preheated. Rubberized and traditional asphalt concretes compared well in void content, indirect tensile strength ratio, rut depth, and wheel-track slope. After optimizing the rubber content added, we laid an experimental road course with the asphalt-rubber mixture.
\end{abstract}

Key words: crumb rubber, road surface course

\section{ISTRAŽIVANJE ASFALTNOG KOLNIKA S DODATKOM SMRVLJENE GUME}

Sažetak: Reciklirani otpadni materijali moraju biti sigurni za okoliš te moraju ispuniti uvjete postavljene standardima za građevne materijale. Obradom otpadnih guma može se dobiti gumeni granulat veličine 0 - $2 \mathrm{~mm}$ koji je pogodan zamjenski dio sitnog agregata u kolničkim konstrukcijama. Članak opisuje ispitivanje asfaltnih mješavina u kojima je gumeni granulat umiješan suhim postupkom te usporedbu dobivenih svojstava sa standardnim asfaltnim mješavinama. Gumeni granulat u asfalnu mješavinu dodavan je bez zagrijavanja, na temperaturi okoliša te prethodno zagrijan. Asfaltne mješavine $s$ gumenim granulatom i standardne asfaltne mješavine uspoređene su preko sljedećih svojstava: udio šupljina, omjer indirektne vlačne čvrstoće, brzina deformacije te relativna dubina kolotraga. Nakon optimizacije udjela dodanog gumenog granulata u mješavini, $s$ asfaltnom mješavinom je izveden zastor pokusne cestovne dionice.

Ključne riječi: smrvljena guma, izvođenje cestovnog zastora 


\section{Introduction}

Tire waste remains an issue in Slovakia because of Slovak legislation and the lack of companies that process used tires. Using tire waste in asphalt mixtures could improve their properties for surface courses and help eliminate tire waste. The properties of asphalt mixtures can be improved by adding new materials to the aggregate or binder. Rubber additives can be introduced to asphalt mixtures in both wet and dry methods. In the wet method, the crushed rubber and asphalt binder are mixed at an elevated temperature to produce the asphalt rubber binder. In the dry method, part of the aggregate is replaced by crumb rubber. Previous research has used the wet method to produce asphalt rubber pavement for experimental road sections [1].

Research on the dry method began in the late 1960s [2], beginning with adding rubber particles to asphalt mixtures. These mixtures contained 3-4 vol. \% of relatively large rubber particles from used tires. These mixtures were improved to create special surface courses with decreased hydroplaning, improved fatigue resistance, and ice resistance during winter. This ice resistance is caused by the rubber particles jutting out of the elastic-plastic asphalt course, breaking the ice as cars pass [2]. Research on mixing asphalt with crumb rubber added by the dry method was eventually ceased because of the short lifetime of the surface course and other complications. Roadways with this type of surface course become unusable after one winter because of insufficient compression. The rubber pieces of these courses tend to clump, reducing the effectiveness of compacting equipment; eventually, the surfaces of the areas with clumped pieces become damaged. The Czech Republic now uses a technical manual [3] that defines tests for asphalt mixtures produced only by the wet method. In contrast, Slovakia has defined many laboratory tests to determine the properties of asphalt pavements made with crushed rubber $[4,5,6]$.

Our research focuses on optimizing the amount of crushed rubber mixed with asphalt mixture in the dry process. We investigated aggregate weights of 1-2 \% crushed rubber.

\section{Crushed Rubber from Used Tires}

Recycled tires provide much rubber, making it important to find ways to use it. Much research has focused on using it in asphalt mixtures, which are applied to different structural layers of pavement [7]. Tire rubber is composed of natural and synthetic rubbers, as well as fillers such as carbon black, sulfur, polymers, oils, paraffin, pigments, steel, and polymer fibers [8]. Rubber granulate is durable, non-toxic, inert, and has low density [9] making it environmentally friendly.

\subsection{Background of Waste Tire Problem}

Since 2001, Slovak law has forbidden storage of waste tires in landfills. Tires can only be used as construction dump material. In 2010, about 28000 tons of used tires were produced in Slovakia. According to the Recycling Fund, this production has been accelerating: in 2001 the country produced 3100 tons of used tires, in 2007 about 16500 tons, and in 2009 about 19600 tons. Slovak plants have a current total recycling capacity for 48000 tons of tires [7].

\subsection{Production of Crushed Rubber - Processing Technology}

Rubber granulate is obtained by using several technologies to reduce particle size. These technologies can be divided into two major categories: ambient grinding and cryogenic grinding [10]. All recycling points in Slovakia produce ground tire rubber by grinding at ambient temperature because doing so is cost effective. 


\section{Materials}

In this research, the surface course was made from mixture AC 11 (asphalt-concrete). This is one of the most common asphalt mixture for local roads in Slovakia, and it is used in many European countries.

\subsection{Aggregates}

All aggregates used in this study were taken from the Hradová stone pit (Košice, Slovakia). The aggregate type was Granodiorit, which has a classic light gray color. The maximum particle size was $11 \mathrm{~mm}$, and there were three size fractions: 8-11 mm, 4-8 mm, and 0-4 mm. The properties of these aggregates meet EN 13108-1 [11], and they are suitable for use in surface asphalt concrete. Next, we combined the fractions for optimal mixture properties according to standards [11]. According to these conditions, we produced a gradation curve (Fig. 1), which we used for all tested samples, with and without rubber. We added rubber with a size fraction of 0-2 mm, and we replaced part of the aggregate with a size fraction of $0-4 \mathrm{~mm}$ (1-2\% weight); the gradation curves of the reference mixture and the mixture with added crumb rubber appear similar.

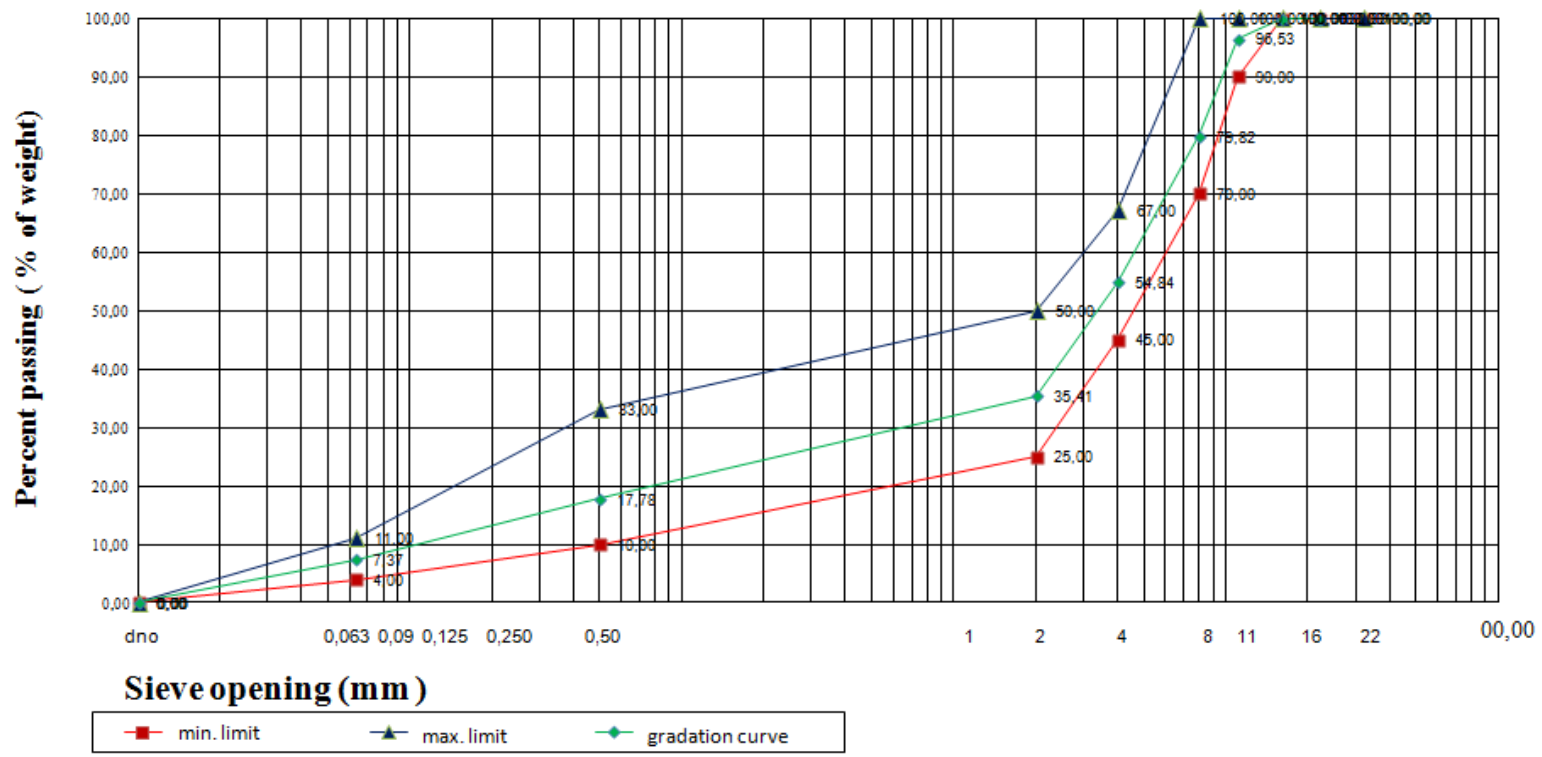

Figure 1. Gradation curve

\subsection{Binder}

The binder was road bitumen 50/70, according to EN 12591 [12] and complying with EN 13108-1 [11]. This is one of the most common binders in Slovakia because of its climate-appropriate properties. Table 1 shows the requirements of the binder, which bitumen 50/70 meets.

The binder content in the asphalt mixture is specified by the theoretical binder optimum content (TOM). The TOM is based on the surface areas of the aggregates in all three size fractions. $6 \%$ of the total mixture weight was used in all samples. 
Table 1. Requirements for binder $50 / 70$ [13]

\begin{tabular}{|l|c|c|}
\hline Characteristic & Standard & Value \\
\hline Penetration $25^{\circ} \mathrm{C} ; 0.1 \mathrm{~mm}$ & STN EN 1426 & $50-70$ \\
\hline Softening point KG $\left[{ }^{\circ} \mathrm{C}\right]$ & STN EN 1427 & $46-54$ \\
\hline Flash point $\left[{ }^{\circ} \mathrm{C}\right]$ & STN EN ISO 2592 & $\geq 230$ \\
\hline Solubility $[\%]$ & STN EN 12592 & $\geq 99$ \\
\hline Breaking point (Fraass method) $\left[{ }^{\circ} \mathrm{C}\right]$ & STN EN 12593 & $\leq-8$ \\
\hline
\end{tabular}

\subsection{Technology}

We chose to add rubber using the dry process because it is less difficult to perform using laboratory equipment and could also be more effective in large-scale asphalt mixing than the wet process. First, the aggregate and binder were heated to a specific temperature (Table 2). The crushed rubber can be heated with the aggregate or added during coating. Heating the crushed rubber with the aggregate improved the reaction between the aggregate, binder, and rubber; a lack of preheating could cause the asphalt mixture to clump. Current methods of producing asphalt mixtures with crumb rubber do not preheat the aggregate and rubber together because doing so can plug the sieve. The maximum rubber temperature was $170{ }^{\circ} \mathrm{C}$ in these experiments, as higher temperature can degradation its structure.

Table 2. Processing temperatures of materials

\begin{tabular}{lcc}
\hline Material & Min. Temperature & Max. Temperature \\
\hline Aggregate & $150^{\circ} \mathrm{C}$ & $180^{\circ} \mathrm{C}$ \\
\hline Binder & $160^{\circ} \mathrm{C}$ & $180^{\circ} \mathrm{C}$ \\
\hline Rubber & - & $170^{\circ} \mathrm{C}$ \\
\hline
\end{tabular}

All components of the mixture were mixed for over 5 min or until the aggregates were completely coated. There are ways to add the rubber: before warming or during mixing. Tests were done on Marshall samples with diameters of $100 \mathrm{~mm}$, made according to EN 12697-30 [13]. The deformation tests needed rectangular samples; we produced samples with dimensions of $260 \times 300 \times 40 \mathrm{~mm}$ by compressing the mixtures with a roller compactor.

\section{Sample Characterization}

We investigated three types of asphalt mixtures:

- $\quad$ Type A: Asphalt mixture without rubber

- $\quad$ Type B: Asphalt mixture with crushed rubber added to aggregate before warming

- $\quad$ Type C: Asphalt mixture with crushed rubber added during mixing without warming.

European standards require assessing the air-void content in the asphalt mixture $\left(V_{m}\right)$, the asphalt binder content $\left(B_{m}\right)$, and the indirect tensile strength ratio (ITSR), as well as deformation tests such as the depth of tracked rut $\left(P R D_{A I R}\right)$ and the wheel-tracking slope $\left(W T S_{A I R}\right)$. These tests assess the water sensitivity of the asphalt mixture and its behavior under traffic loading. 


\subsection{Results}

Table 4 lists the results of the tested samples. Only some mixtures were tested for $P R D_{A I R}$ and $W T S_{A I R}$ because of technological difficulties. The tests were performed according to the European standards listed in the tables.

Table 3. Results for samples A and C

\begin{tabular}{|c|c|c|c|c|c|c|c|}
\hline & $\begin{array}{c}\text { AC11 } \\
\text { SAMPLE A }\end{array}$ & $\begin{array}{l}\text { AC11+1,25GG } \\
\text { SAMPLE C }\end{array}$ & $\begin{array}{l}\text { AC11+1,5GG } \\
\text { SAMPLE C }\end{array}$ & $\begin{array}{l}\text { AC11+1,75GG } \\
\text { SAMPLE C }\end{array}$ & \multicolumn{2}{|c|}{ Requirements } & Code Standards \\
\hline$V_{m}[\%]$ & 4.27 & 2.56 & 7.80 & 3.75 & 2.5 & 4.5 & EN 12697-8 \\
\hline$B_{m}[\%]$ & 6 & 6 & 6 & 6 & \multicolumn{2}{|c|}{$\geq 5.4$} & EN 12697-1 \\
\hline ITS [GPa] & 0.0011 & 0.0015 & 0.00108 & 0.00136 & \multicolumn{2}{|c|}{-} & EN 12697-23 \\
\hline ITS $w$ [GPa] & 0.0013 & 0.0012 & 0.00084 & 0.00117 & \multicolumn{2}{|c|}{-} & EN 12697-23 \\
\hline ITSR [\%] & 118.1 & 83.2 & 77.3 & 85.9 & \multicolumn{2}{|c|}{$\geq 70$} & EN 12697-12 \\
\hline$P R D_{A I R}[\%]$ & - & 1.53 & 2.56 & 2.91 & \multicolumn{2}{|c|}{$\leq 5$} & EN 12697-22 \\
\hline $\begin{array}{l}\text { WTS } S_{A I R} \\
{\left[\mathrm{~mm} / 10^{3}\right.} \\
\text { cycles] }\end{array}$ & - & 0.019 & 0.013 & 0.032 & \multicolumn{2}{|c|}{$\leq 0.1$} & EN 12697-22 \\
\hline
\end{tabular}

$\left(V_{m}\right.$ - air-void content in asphalt mixture [\%], $B_{m}$ - asphalt binder content in asphalt mixture [\%], ITS $d_{d}$ indirect tensile strength of dry sample [GPa], ITS - indirect tensile strength of wet sample [GPa], ITSR - indirect tensile strength ratio [\%], PRD ${ }_{A I R}-[\%], W T S_{A I R}$ - wheel-tracking slope on air [mm per 1000 cycles].)

Table 4. Results for samples B, and C

\begin{tabular}{lcccccc}
\hline & $\begin{array}{c}\text { AC11+1 GG } \\
\text { SAMPLE C }\end{array}$ & $\begin{array}{c}\text { AC11+2GG } \\
\text { SAMPLE C }\end{array}$ & $\begin{array}{c}\text { AC11+1,75GG } \\
\text { SAMPLE B }\end{array}$ & Requirement & Code Standard \\
\hline$V_{m}[\%]$ & 4.1 & 7 & 6.67 & 2.5 & 4.5 & EN 12697-8 \\
\hline$B_{m}[\%]$ & 6 & 6 & 6 & $\geq 5.4$ & EN 12697-1 \\
\hline$I T S_{d}[\mathrm{GPa}]$ & 0.00105 & 0.00078 & 0.0013 & - & EN 12697-23 \\
\hline$I T S_{w}[\mathrm{GPa}]$ & 0.00127 & 0.00067 & 0.0009 & - & EN 12697-23 \\
\hline$I T S R[\%]$ & 121 & 85.9 & 74.9 & $\geq 70$ & EN 12697-12 \\
\hline
\end{tabular}

The results of these tests were compared with requirements in EN 13108-1 [11]; only some samples were of high enough quality.

\section{Application Results}

Using asphalt rubber mixes is one way to use tire waste. These results show that asphalt-rubber mixtures have properties equal or better than those of traditional asphalt mixes. The mixture contents greatly influence its properties. According to these results, the optimal amount of rubber particles is $1.25 \%$ of the aggregate weight. The rubber content should be chosen with regards to the aggregate and binder contents. 
After laboratory testing, we used a mixture to pave an experimental road. We removed the old surface course and replaced it with an asphalt concrete with added crushed rubber, $1.2 \%$ of the mixture weight. Addibit L300 additive was used in this pavement because it improves the affinity between the aggregate and bitumen. The crushed rubber from used tires was produced by the company V.O.D.S. a.s.; this product fulfills the environmental and health standards of the European Union.

The experimental road section was $200 \mathrm{~m}$ long, and the pavement was $40 \mathrm{~mm}$ thick. The weather during course laying was acceptable; the air temperature was $15-25^{\circ} \mathrm{C}$. The mixture temperature after output from the plant was $160^{\circ} \mathrm{C}$. The pavement was laid and compacted $1 \mathrm{~h}$ after mixing, and the pavement temperature on the road was over $135^{\circ} \mathrm{C}$. The mixing cycle was set to $\sim 7 \mathrm{~s}$ longer than ordinary mixing. Crushed rubber was added into the mixing drum during mixing, $10 \mathrm{~kg}$ at a time. The mixtures did not have compaction problems, were not sticky, and did not have a bad smell. Workers on the road and in the plant confirmed that producing this mixture was much the same as producing traditional asphalt pavement. Figures 2-4 show photographs of laying and compacting the experimental road.

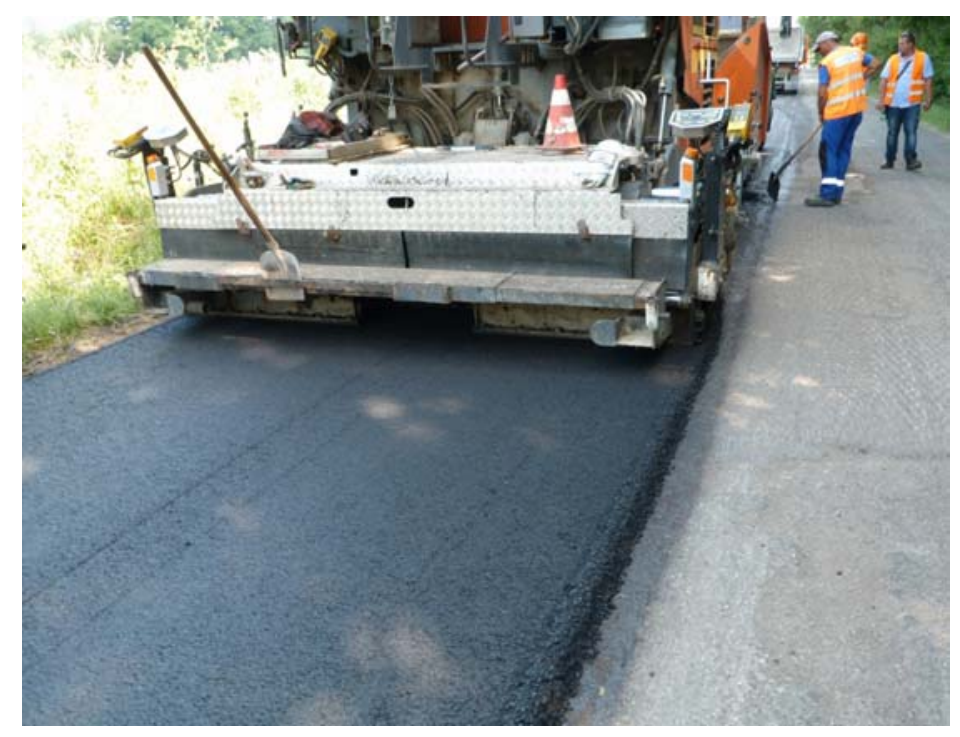

Figure 2. Laying the surface course

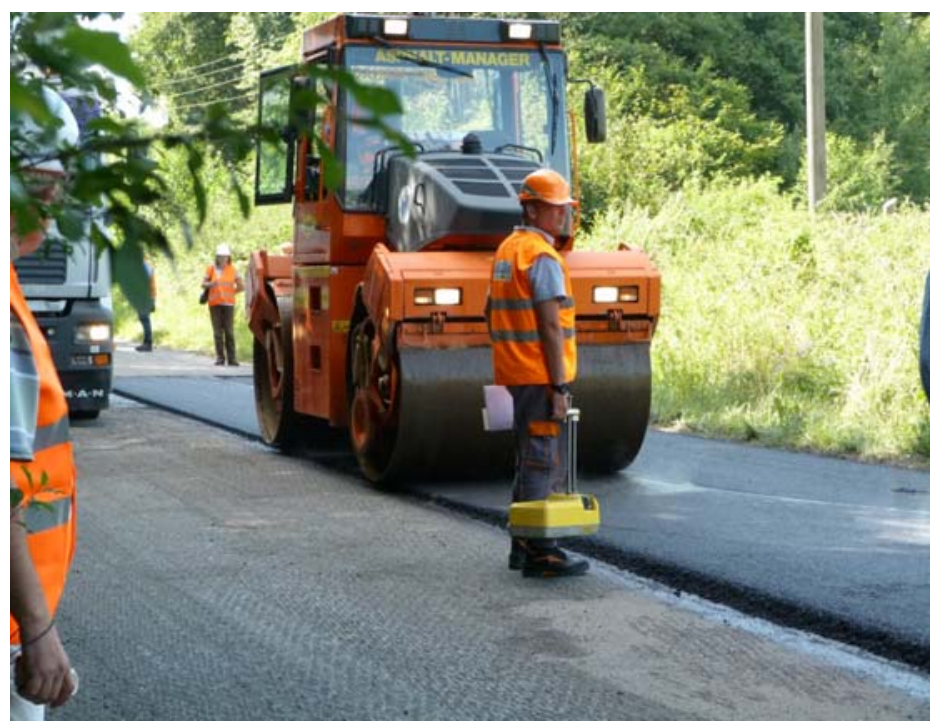

Figure 3. Compacting the layer and density control 


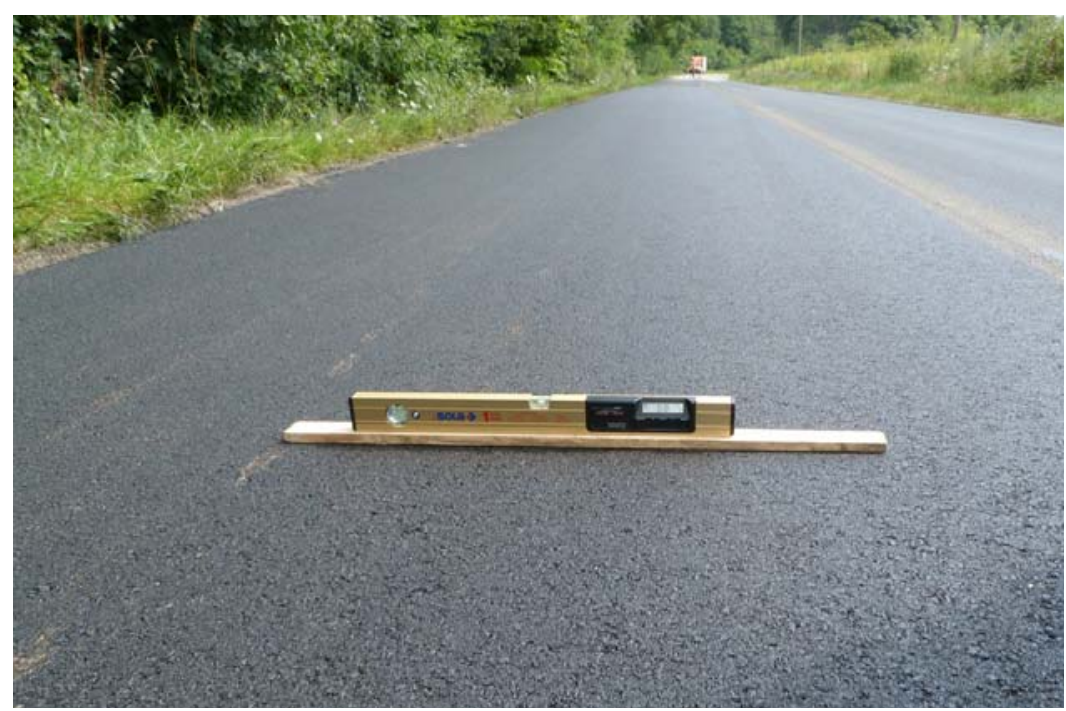

Figure 4. Inclinometer on new layer

\section{Conclusion}

We studied using waste tire rubber in asphalt mixtures. For mixtures with rubber contents of $1.25 \%, 1.5 \%$, and $1.75 \%$ mixed at ambient temperature, their void contents and indirect tensile strength ratios were no worse than those of traditional mixtures. Tests of the depth of the tracked rut and the wheel-tracking slope revealed the optimum mixture to be that with $1.25 \%$ rubber content. This mixture had good water resistance and led to lower wheel deformation than ordinary asphalt pavements. After laboratory testing, an asphalt mixture with $1.25 \%$ rubber was used to lay an experimental surface course. This experimental course allows us to observe other properties such as fatigue and stiffness, durability, maintenance costs, and acoustic properties in real conditions. The test road section with the rubberized surface course was easily compressed and laid, did not smell, and required no extra investments over traditional courses.

\section{Acknowledgements}

The paper presents the results of the research from the Centre for Progressive Constructions and Technologies in Transportation Engineering. The Centre was supported by the Slovak Research and Development Agency under contract No. SUSPP-0013-09 as well as by the companies Inžinierske stavby and EUROVIA SK.

The research was performed within project NFP 26220220051, Development of Progressive Technologies for Utilization of Selected Waste Materials in Road Construction Engineering, supported by the European Union Structural Funds.

\section{References}

[1] Roberts, F. L. et al. 1989: Investigation and evaluation of ground tire rubber in hot mix asphalt. National Center for Asphalt Technology, NCAT Report No. 89-3

[2] Esch, D. C. 1984: Asphalt pavements modified with coarse rubber particles. Design, construction and ice control observations. United States.

[3] Kudrna, J.; Dašek, O. 2009: TP 148. Hutněné asfaltové vrstvy s asfaltem modifikovaným pryžovým granulátem, Brno, Czech Republic (in Slovakian) 
[4] Loveček, Z. 2009: Možnosti využitia ojazdených pneumatík v asfaltových zmesiach cestného stavitel'stva. Celoštátna konferencia: 30. CONECO Recyklácia stavebného odpadu. Bratislava, Slovakia (in Slovakian)

[5] Loveček, Z.; Budínsky, V.; Koval', P. 2009: Výroba a overovanie asfaltových zmesí s modifikovaným asfaltom gumovým granulátom. 11. Medzinárodná vedecká konferencia, Žilina 28.4-29. 4. (in Slovakian)

[6] Mandula J.; Hudák M. 2011: Low temperature asphalt mixtures with crushed rubber from used tires, Journal of Civil Engineering, Volume 6, Issue 1, pp 33-42

[7] Luknár, M. 2012: Overovanie využiteĺnosti recyklátu z drvenia pneumatík do asfaltových zmesí. Available on http://stavebni-technika.cz/clanky/overovanie-vyuzitelnosti-recyklatu-z-drvenia-pneumatik-do-asfaltovychzmesi/ (in Slovakian)

[8] Evans, A.; Evans, R. 2006: The Composition of a Tyre: Typical Components, The Waste \& Resources Action Programme, United Kingdom

[9] Chalker-Scott, L. 2008: The Myth of Rubberized Landscapes "Recycled rubber mulch is an environmentally friendly, non-toxic choice for landscapes" United States

[10] Radvanská, A. 2006: Spracovanie odpadových pneumatík. In: Strojárstvo - ISSN 335-2938, Volume 10, Issue 12, pp 60-61., Available online: http://www.strojarstvo.sk/docwww/SK/263/263.pdf (in Slovakian)

[11] EN 13108-1:2006 Bituminous mixtures. Material specifications. Asphalt Concrete, 30 June 2006

[12] EN 12591:2009 Bitumen and bituminous binders. Specifications for paving grade bitumens, 30 September 2009

[13] EN 12697-30:2012 Bituminous mixtures. Test methods for hot mix asphalt. Specimen preparation by impact compactor 